\title{
Occurrence and distribution of pepper veinal mottle virus and cucumber mosaic virus in pepper in Ibadan, Nigeria
}

\author{
Olawale Arogundade ${ }^{1 *}$, Olusegun Samuel Balogun² and Kehinde Titilope Kareem ${ }^{1}$
}

\begin{abstract}
Viral diseases constitute obstacles to pepper production in the world. In Nigeria, pepper plants are primarily affected by pepper veinal mottle virus (PVMV), Cucumber mosaic virus (CMV), Pepper leaf curl Virus (TLCV), Tobacco mosaic virus (TMV), Pepper mottle virus (PMV) and a host of other viruses. The experiment was carried out with a diagnostic survey on the experimental field of the National Horticultural Research Institute, Ibadan, Nigeria and on pepper farms in six local government areas within Ibadan Oyo State, Nigeria, forty samples were collected from each of the farms. Diseased samples were obtained from the field and taken to the laboratory for indexing. In ELISA test some of the samples from the pepper farms showed positive reaction to single infection with PVMV (36.79\%), CMV (22.14\%) while some others showed positive reaction to mixed infection of the two viruses (10\%) but some also negative reaction to PVMV and CMV antisera (31.07).
\end{abstract}

Keywords: Antisera, CMV, Diagnostic survey, ELISA, PVMV, Nigeria

\section{Introduction}

Plant virus diseases cause major losses to agricultural crops around the world. Chemical agents similar to fungicides and bactericides are not effective in controlling virus diseases. Strategies for virus management in plant are mostly aimed at eradicating the source of infection to prevent it from reaching the crop and interfering with the movement of vectors in order to prevent the spread of the disease. However, the most effective means of controlling virus diseases is through cultivating the virus-resistant varieties.

Generally, viral infection causes visible symptoms such as various forms of mosaic and distortions in plants with consequent reductions in crop growth and yield. While reduction in plant size is the most general symptom induced by virus infection, there is probably some stunting of growth even with 'masked' or 'latent' infections, where the systemically infected plant shows no obvious sign of disease [1]. In nature, higher plants are commonly co-infected with multiple viruses and a number of disease

\footnotetext{
* Correspondence: arogundade_olawale@yahoo.co.uk

${ }^{1}$ National Horticultural Research Institute, Idi Ishin, Jericho Reservation Area, P.M.B 5432, Dugbe, Ibadan, Oyo State, Nigeria

Full list of author information is available at the end of the article
}

syndromes are caused by interaction of two independent viruses. The accumulation dynamics of the interacting viruses in such mixed infection often change drastically [2]. Besides, mixed infections with two unrelated viruses, which are common in field plants, especially in tropical areas, often produce a more severe disease than that caused by either virus alone. For instance, tobacco on infection with potato virus $\times(\mathrm{PVX})$ and potato virus $\mathrm{Y}$ normally develop a more severe disease than that induced by either virus alone [3].

Pepper veinal mottle virus (PVMV) was first recognized as a distinct member of a group of viruses which was originally designated the Potato virus $Y$ group but was later renamed the Potyvirus group [4]. PVMV occurs mainly in Africa, although it affects Capsicum annuum L. crops in Afghanistan [5] and India [6]. PVMV also occurs in Capsicum spp. in Sierra Leone and Zaire, [7]. PVMV has been reported in several West African countries, and in some parts of Nigeria $[8,9]$. There was a report that a strain of PVMV occurs naturally in Telfairea occidentalis (Cucurbitaceae) in Nigeria [10]. Strains of the virus are also experimentally transmissible to at least 35 species of the Solanaceae and to nine species of five other families (Aizoaceae, Amaranthaceae, Apocynaceae, Chenopodiaceae
C Biomed Central

ㄷ 2012 Arogundade et al; licensee BioMed Central Ltd. This is an Open Access article distributed under the terms of the Creative Commons Attribution License (http://creativecommons.org/licenses/by/2.0), which permits unrestricted use, distribution, and reproduction in any medium, provided the original work is properly cited. 
and Rutaceae) [11-14]. Symptoms expressed by the leaves of PVMV-infected plants include chlorosis of the veins, followed by systemic interveinal chlorosis, mottle, and small distortion of leaves and at times leaf abscission and fruit distortion occur [11]. There have been reports of one hundred percent losses of marketable pepper fruit due to infection with pepper viruses causing whole field to be abandoned prior to harvest and in some areas making cultivation of pepper to be uneconomical in some parts of Nigeria [8].

Cucumber mosaic virus (CMV) is worldwide in distribution. The virus causing cucumber mosaic has perhaps a wider range of host and attacks a greater variety of vegetables, ornamentals, weeds, and other plants than other viruses [15]. CMV is transmitted mainlyby the green peach aphid, Myzus persicae, and by Aphis gossypii, but it can be transmittedby other species of aphids [16].

In this paper we report the distribution of PVMV and CMV infection in pepper plants within Ibadan, Oyo state, Nigeria.

\section{Materials and methods}

Survey for Pepper veinal mottle virus, genus Potyvirus, and Cucumber mosaic virus, genus Cucumovirus was conducted during the 2009 planting season in seven locations in Ibadan, Oyo State in the southwest agroecological zone of Nigeria.

The locations were the experimental field of the National Horticultural Research Institute (NIHORT), Lagelu Local government area, Akinyele Local government area, Egbeda Local government area, Ona Ara Local government area, Oluyole Local government area and Ido Local government area.

\section{Collection of diseased leaf samples}

Diseased Leaf Samples were randomly collected from the experimental fields containing pepper in NIHORT while in the Local government areas two cultivated pepper farms were randomly surveyed per Local government. On each site 20 plants were randomly sampled from the population of plants on the field. Forty plants were sampled per location from cultivated pepper plants showing symptoms of mosaic, chlorosis, yellowing, stunting and mottle making a total of two hundred and eighty samples in all. The sampled leaves were then stored under Calcium chloride and were placed in the refrigerator prior to indexing.

\section{Virus detection}

International Iinstitute of Tropical Agriculture (IITA) Virology laboratory modified protocols for Direct antigen coating (DAC - ELISA) was used for the detection of the presence of PVMV and CMV both from the forty infected pepper leaf samples collected per location. The
PVMV and CMV antibodies used were AAB 328 antiserum diluted in the ratio 1:1000 and 1:3000 respectively with Phosphate Buffered Saline (PBS-T) $(0.05 \%$ Tween 20: pH 7.4: $8.0 \mathrm{~g} \mathrm{NaCl}, 0.2 \mathrm{~g} \mathrm{KH}_{2} \mathrm{PO}_{4}, 1.1 \mathrm{~g} \mathrm{Na}_{2} \mathrm{HPO}_{4}$ $0.2 \mathrm{~g} \mathrm{KCl}, 0.2 \mathrm{~g} \mathrm{NaNO}_{3}$ in $1 \mathrm{l} \mathrm{H}_{2} \mathrm{O}+0.5 \mathrm{ml}$ Tween 20 $(0.05 \%)$ ) from the Virology Laboratory of the International Institute of Tropical Agriculture (IITA) Ibadan.

\section{Viral indexing protocols}

One hundred micro litre of antigen (e.g. sap) ground at 0.1 $\mathrm{g}$ of leaf sample in $1 \mathrm{ml}$ of coating buffer was dispensed into each well of ELISA plate. The plate was then incubated at $37^{\circ} \mathrm{C}$ for $1 \mathrm{~h}$ and later washed three times with PBS-T after the incubation period. Cross adsorption was made by grinding $1 \mathrm{~g}$ of healthy pepper leaf in $20 \mathrm{mls}$ of conjugate buffer conjugate buffer $(1 / 2 \mathrm{PBS}+0.05 \%$ Tween $20+0.02 \%$ egg albumin $+0.2 \%$ PVP +0.02 g NaN3). $100 \mu \mathrm{l}$ of PVMV and CMV polyclonal (AAB 328) antisera diluted 1:1000 and 1:3000 in the adsorption solution was added to each of the ELISA plate and then incubated at $37^{\circ} \mathrm{C}$ for $1 \mathrm{~h}$. After incubation the ELISA plate was washed three times with PBS-T. $100 \mu \mathrm{l}$ of protein, A- alkaline phosphatase conjugate diluted in the ratio 1:15000 in conjugate buffer $(1 / 2$ PBS $+0.05 \%$ Tween $20+0.02 \%$ egg albumin $+0.2 \%$ PVP $+0.02 \mathrm{~g} \mathrm{NaN3}$ ) was added per well and the plate incubated at $37^{\circ} \mathrm{C}$ for $1 \mathrm{~h}$. The plate was washed three times with PBS-T. $100 \mu \mathrm{l}$ of $0.001 \mathrm{~g} / \mathrm{ml}$ of pnitrophenyl phosphate substrate in substrate buffer $(97 \mathrm{ml}$ diethanolamine $+800 \mathrm{ml} \mathrm{H}_{2} \mathrm{O}+0.2 \mathrm{~g} \mathrm{NaNO}_{3}$ add $\mathrm{HCl}$ to give $\mathrm{pH}$ 9.8) was added per well and incubated at room temperature for one hour. For all incubations plates were covered with ELISA cover plates to avoid edge effects and to maintain uniform temperature. Healthy pepper plants (Capsicum sp.) were used as negative control while PVMV and CMV infected Capsicum sp were used as positive control. After one hour the absorbance was measured at $405 \mathrm{~nm}$ using multiscan ELISA reader. The samples were considered positive when the ELISA reading exceeded that of the healthy control or was at least twice the reading for the healthy control.

\section{Results and discussion}

All the farms visited recorded the presence of PVMV and CMV as a single infection as well as mixed infection in some cases. Out of the two hundred and eighty leaf samples suspected to be virus infected collected from the farmers field in Ibadan, Oyo State of Nigeria 36.79\% tested positive to PVMV, 22.14\% tested positive to CMV, $10 \%$ tested positive to both PVMV and CMV through the serological test used, while $31.07 \%$ tested negative to the two antisera (Figure 1). However, from Table 1, out of the 40 leaf samples collected from each of the survey point Lagelu have the highest single infection of PVMV [3] while Ido have the highest single infection of CMV 


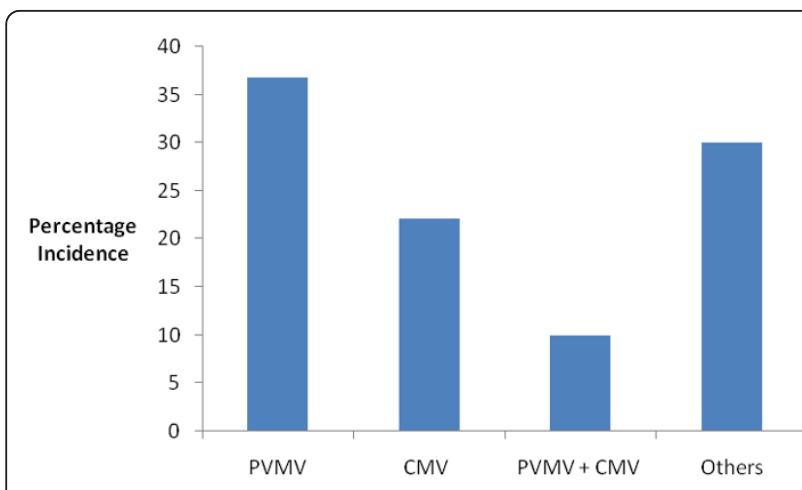

Figure 1 Percentage of PVMV, CMV, PVMV + CMV and Other Virus diseases of pepper in Ibada.

[12] while Egbeda have the highest incidence of mixed infection of PVMV and CMV [9].

All the pepper farms surveyed within Ibadan showed differences in PVMV and CMV as observed in the percentage viral incidence (Figure 2). The percentage viral incidence of PVMV and CMV ranges between $55.0 \%$ in Ona-ara to $87.50 \%$ in Ido.

Pepper is highly susceptible to virus diseases in Ibadan, Oyo state, Nigeria as all samples picked from all the surveyed locations showed different viral symptoms ranging from different degree of mosaic, mottle, yellowing, stunting, puckering and in some cases reduction in leaf size which was similar to the earlier described symptoms of PVMV and CMV by Atiri [17] and Arogundade et al. [18]. It was however observed that from all the six local governments used as study area in this survey and the experimental field of NIHORT, pepper is mostly infected with PVMV than CMV and the mixed infection of PVMV and CMV, however the combine effect of PVMV and CMV is more on pepper than all other vegetable viruses combine as observed during the survey (Figure 1).

The high percentage incidence of PVMV and CMV in the experimental field of NIHORT could be as a result of numerous alternative host species surrounding the pepper field such as tomato, solanum, cucurbits and a host of other vegetables. This corroborates the findings of Alegbejo [19] who reported that the proximity of

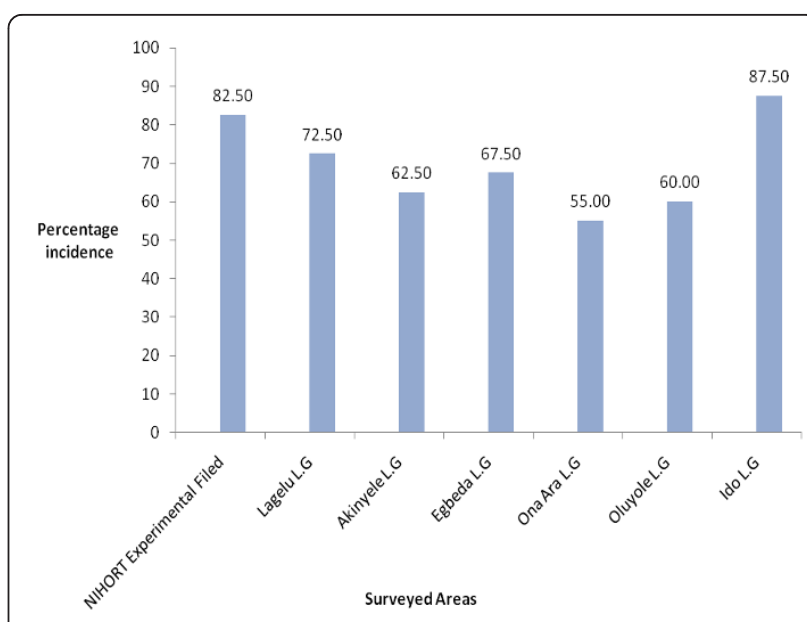

Figure 2 Percentage Incidence of PVMV and CMV in NIHORT experimental Station and Six other areas of Oyo State.

pepper plants to certain important weed hosts also has contributed greatly to the spread of viral diseases of pepper. These weeds include Solanum nigrum, S. gracil, Physalis angulata, Vigna rosea, Vigna sinensis, Commelina nudiflora, Petunia hybrida, Physalis floridana, P. micrantha and Solanum incanum.

\section{Author details}

${ }^{1}$ National Horticultural Research Institute, Idi Ishin, Jericho Reservation Area, P.M.B 5432, Dugbe, Ibadan, Oyo State, Nigeria. ${ }^{2}$ University of Ilorin, Faculty of Agriculture, Crop Protection Department, P.M.B 1515, Ilorin, Kwara State, Nigeria.

Received: 13 July 2011 Accepted: 11 April 2012 Published: 11 April 2012

\section{References}

1. Matthews REF: Plant Virology. 3 edition. San Diego: Academic; 1991, 835

2. Otsuki Y, Takebe I: Double infection of isolated tobacco mesophyll protoplasts by unrelated viruses. J Gen Virol 1976, 30:309-316.

3. Vance VB: Replication of potato virus $x$ is altered in co-infections with potato virus Y. Virology 1991, 182:486-489.

4. Harrison BD, Finch JT, Gibbs AJ, Hollings M, Shepherd RJ, Valenta V, Wetter C: Sixteen groups of plant viruses. Virology 1971, 45:356-363.

5. Lal SB, Singh S: Identification of some virus diseases of vegetable crops in Afghanistan. Plant Prot Bull (Faridabad) 1988, 36(2):83-89.

6. Nagaraju R, Reddy HR: Occurrence and distribution of bell pepper viruses around Bangalore. Current research, University of Agricultural Sciences, Bangalore; 1980:10(9/10):155; 6.

Table 1 Distribution of PVMV and CMV in Ibadan

\begin{tabular}{ccccc}
\hline Location & Number of samples collected & PVMV & CMV & PVMV + CMV \\
\hline NIHORT Experimental Field & 40 & 17 & 10 & 6 \\
Lagelu Local Government & 40 & 19 & 10 & 0 \\
Akinyele Local Government & 40 & 14 & 7 & 4 \\
Egbeda Local Government & 40 & 11 & 8 & 8 \\
Ona Ara Local Government & 40 & 9 & 6 & 7 \\
Oluyole Local Government & 40 & 15 & 4 & 5 \\
Ido Local Government & 40 & 18 & 13 & 4 \\
\hline
\end{tabular}


7. Huguenot C, Furneaux MT, Clare J, Hamilton Rl: Sero-diagnosis of Pepper veinal mottle viru in West Africa using specific monoclonal antibodies in DAS-ELISA. J Phytopathol 1996, 144:29-32.

8. Alegbejo MD, Uvah II: Effect of intercropping pepper with tall companion crops on the incidence of Pepper veinal mottle viru on pepper. Nigerian J Entomology 1987, 7:82-87.

9. Fajinmi AA: The incidence, spread and possible control strategies of Pepper veinal mottle Potyvirus (PVMV) disease on pepper (Capsicum annuum.L.) in Nigeria. Ph. D thesis University of Ibadan Oyo State Nigeria; 2006.

10. Atiri Gl: A disease of fluted pumpkin (Telfairia occidentalis Hook.f.) caused by a yellow vein clearing strain of Pepper veinal mottle virus in Nigeria. J Plant Prot Tropics 1986, 3(2):105-110.

11. Brunt AA, Kenten RH, Phillips S: Symptomatologically distinct strains of Pepper veinal mottle viru from four (4). West African Solanaceous crops. Ann App Biology 1978, 88:115-119.

12. Igwegbe ECK, Waterworth HE: Properties and serology of the strain of Pepper veinal mottle virus isolated from eggplant (Solanum melongena L.) in Nigeria. Phytopathologische Zeitschrift 1982, 103(1):9-12.

13. Ladipo JL, Roberts IM: Pepper veinal mottle viru associated with a streak disease of tomato in Nigeria. Ann Appl Biol 1977, 87:133-138.

14. Prasada Rao, RDVJ Yaraguntaiah RC: The occurrence of Pepper veinal mottle virus on chilli in India. Mysore J Agric Sci 1979, 13(4):445-448; 6.

15. Crescenzy $A$ : Cucumber mosaic cucumovirus populations in Italy under natural epidemic conditions and after a satellite - mediated protection test. Plant Dis 1993, 77:28-33.

16. Palukaitis $P$, Roossinck MJ, Dietzgen RG, Francki RIB: Cucumber mosaicvirus. Adv Virus Res 1992, 41:281-349.

17. Alegbejo MD: Identification of a weed host of Pepper veinal mottle virus in Northern Nigeria. Samaru J Agric Res 1987, 5(1 and 2):65-70.

18. Atiri Gl: Progress of Pepper veinal mottle viru disease in Capsicu peppers. Crop Prot 1992, 11(3):255-259.

19. Arogundade O, Balogun OS, Shokalu O, Aliyu TH: Influence of Cowpea Mottle Virus and Cucumber Mosaic Virus on the Growth and Yield of six Lines of Soybean (Glycine max L.). J Agric Sci 2010, 2(1):72-78.

doi:10.1186/1743-422X-9-79

Cite this article as: Arogundade et al:: Occurrence and distribution of pepper veinal mottle virus and cucumber mosaic virus in pepper in Ibadan, Nigeria. Virology Journal 2012 9:79.

\section{Submit your next manuscript to BioMed Central and take full advantage of:}

- Convenient online submission

- Thorough peer review

- No space constraints or color figure charges

- Immediate publication on acceptance

- Inclusion in PubMed, CAS, Scopus and Google Scholar

- Research which is freely available for redistribution

Submit your manuscript at www.biomedcentral.com/submit
Biomed Central 